University of Nebraska - Lincoln

DigitalCommons@University of Nebraska - Lincoln

Agronomy \& Horticulture -- Faculty Publications

Agronomy and Horticulture Department

1995

\title{
In vitro starch disappearance procedure modifications
}

C. J. Richards

University of Nebraska-Lincoln, Chris.Richards@okstate.edu

Jeffrey F. Pedersen

University of Nebraska-Lincoln, jpedersen1@unl.edu

R. A. Britton

University of Nebraska-Lincoln

R. A. Stock

University of Nebraska-Lincoln

C. R. Krehbiel

University of Nebraska-Lincoln, clint.krehbiel@unl.edu

Follow this and additional works at: https://digitalcommons.unl.edu/agronomyfacpub

Part of the Agricultural Science Commons, Agriculture Commons, Agronomy and Crop Sciences Commons, Botany Commons, Horticulture Commons, Other Plant Sciences Commons, and the Plant Biology Commons

Richards, C. J.; Pedersen, Jeffrey F.; Britton, R. A.; Stock, R. A.; and Krehbiel, C. R., "In vitro starch disappearance procedure modifications" (1995). Agronomy \& Horticulture -- Faculty Publications. 963. https://digitalcommons.unl.edu/agronomyfacpub/963

This Article is brought to you for free and open access by the Agronomy and Horticulture Department at DigitalCommons@University of Nebraska - Lincoln. It has been accepted for inclusion in Agronomy \& Horticulture -Faculty Publications by an authorized administrator of DigitalCommons@University of Nebraska - Lincoln. 


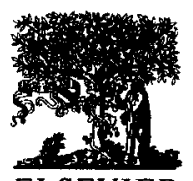

Animal Feed Science and Technology 55 (1995) 35-45

\title{
In vitro starch disappearance procedure modifications is
}

\author{
C.J. Richards ${ }^{\text {a }}$, J.F. Pedersen ${ }^{\text {b }}$, R.A. Britton ${ }^{\dagger, a}$, R.A. Stock ${ }^{\text {a,* }}$, \\ C.R. Krehbiel ${ }^{\text {a }}$ \\ a Department of Animal Science, University of Nebraska, Lincoln, NE 68583-0908, USA \\ ${ }^{\mathrm{b}}$ USDAARS, Department of Agronomy, University of Nebraska, Lincoln, NE 68583-0908, USA
}

Received 27 October 1994; accepted 1 March 1995

\begin{abstract}
Four in vitro experiments evaluated the effects of ruminal fluid inoculum:artificial saliva ratios, grinder type, grind size, and diet of ruminal fluid donor on in vitro starch disappearance. Experiment 1 examined rates of starch disappearance and coefficients of determination obtained by linear regression of starch disappearance using five grain sorghum (Sorghum bicolor (L.) Moench) lines, a corn (Zea mays L.) control, and a wheat (Triticum aestivum L.) control. Grains were incubated for 4,8 , 12,16 , and $20 \mathrm{~h}$ with inoculum varying in proportion of ruminal fluid and artificial saliva $(1: 1,1: 2$, $1: 3$, and 1:4). In vitro rates of starch disappearance and coefficients of determination were similar for the $1: 2,1: 3$, and $1: 4$ inoculum dilutions and were higher (quadratic, $P<0.01$ ) than the $1: 1$ dilution. As the proportion of artificial saliva in the inoculum increased, in vitro $\mathrm{pH}$ increased (linear, $P<0.01$ ). In Experiment 2, six grain sorghum lines and a corn control were ground through a 1-mm screen in a Udy (cyclone type) or Wiley mill. Starch disappearance for samples ground using a Udy mill were higher $(P<0.01)$ than for samples ground in a Wiley mill and approached $90 \%$ digestion in $8 \mathrm{~h}$. Experiment 3 compared six grain sorghum lines and a corn control ground through a Wiley mill equipped with either a 1-mm or 2-mm screen. Starch disappearance of samples ground through a 1$\mathrm{mm}$ screen were lower $(P<0.10)$ when compared with samples ground through a $2-\mathrm{mm}$ screen. In Experiment 4, the effect of grain type (corn, sorghum, or 50:50 corn:sorghum) in $92.5 \%$ concentrate diets of ruminal fluid donors was compared in a replicated $3 \times 3$ Latin square design. Six grain sorghum lines and five corn hybrids were evaluated with in vitro digestion. Ranking by in vitro rate of starch digestion was not affected $(P>0.10)$ by grain type fed; however, absolute rates of digestion varied among inoculate sources. Grinder, grind size, and ruminal fluid inoculum:artificial saliva ratios affected rate of starch disappearance in samples digested in vitro. Diet of ruminal fluid donor affected the rate of starch digestion, but not the relative ranking of the grains. If rates are to be compared across
\end{abstract}

\footnotetext{
Journal article number 10905 of the University of Nebraska Agricultural Research Division, Lincoln, NE.

* Corresponding author.

† Deceased April, 1994.
} 
in vitro runs for different grains, these processing and dietary factors must be kept constant.

Keywords: Starch; Inoculate sources; Ruminal fluid

\section{Introduction}

Grain sorghum is a very water-efficient crop that also exhibits high drought and heat tolerance. As irrigation costs rise, and concerns about water usage increase, its importance as a feed-grain crop will certainly increase as well. Grain sorghum is used primarily as an energy source in livestock feeds with a large portion of this being used for cattle diets. Efficient utilization of grain by ruminants is due to ruminal starch digestion ( $\varnothing$ rskov, 1986). The degradation of starch in grain sorghum has been shown by many investigators to be variable whether measured in the laboratory, digestibility trials, or performance trials (Sherrod et al., 1969; McCollough et al., 1972; Hibberd et al., 1979; Hibberd et al., 1983; Rooney and Pflugfelder, 1986; Streeter et al., 1986; Streeter et al., 1990; Streeter et al., 1991).

In vitro rate of starch disappearance (IVRSD) was correlated positively $\left(R^{2}=0.99\right)$ to gain:feed ratio when cattle were finished with sorghum grain (Wester et al., 1992). However, in order for the IVRSD technique to be useful for improving rate of sorghum starch digestibility through cooperation with plant breeders, variation within and between in vitro runs must be reduced. Time allocated per sample must be reduced because of the very large numbers of samples to be analyzed. Reducing the multiple incubation times needed for calculation of rates of digestion to a single point in time would allow for both a reduction in labor and reduce the number of sub-samples per sample needed to calculate a rate within a run. Therefore experiments were conducted to determine the effects of ruminal fluid inoculum:artificial saliva ratios, grinder, grind size, and diet of ruminal fluid donor on IVRSD.

\section{Materials and methods}

\subsection{Experiment 1 -Ruminal fluid:inoculum ratios}

Five grain sorghum lines (SC203, SC215, SC242, SC460, and SC835) selected from the U.S. Department of Agriculture, Agricultural Research Service Genetic Resources Information Network data base for known diversity in grain size (4.5, 3.0, 3.0, 5.0, $2.5 \mathrm{~mm}$, respectively) and hardness rating $(6.5,3.8,6.5,5.0,2.4 \mathrm{~kg}$ of pressure to crack seeds, respectively), a control corn hybrid (Pioneer 3183, Pioneer Hi-Bred International, Inc., Johnston, IA), and a wheat control (mixed varieties) were used to examine the effects of ruminal fluid inoculum:artificial saliva (McDougall, 1948) ratios of 1:1, 1:2, 1:3, and 1:4 on IVRSD, coefficients of determination, and $\mathrm{pH}$. Grain samples were cleaned by hand to remove any foreign material and then ground to pass through a 1-mm screen in a Wiley mill Model 3 (Arthur H. Thomas Co., Philadelphia, PA) ${ }^{1}$.

\footnotetext{
' [3]Mention of a trademark, proprietary product, or a vendor does not constitute a guarantee or warranty of the University of Nebraska or the USDA and does not imply its approval to the exclusion of other products or vendors that may also be suitable.
} 
Starch in the original sample was determined as $\alpha$-linked glucose polymers by a modified MacRae and Armstrong (1968) procedure. Triplicate $0.1 \mathrm{~g}$ grain samples were weighed into 50-ml test tubes with Teflon-lined screw caps. Samples were mixed with $25 \mathrm{ml}$ of 0.1 $\mathrm{M}$ acetate buffer in $0.2 \%(\mathrm{w} / \mathrm{v}$ ) benzoic acid and $50 \mu$ l of heat stable $\alpha$-amylase enzyme (Takatherm L-340; Valley Research Inc., South Bend, IN) was added before being capped and gently vortexed. Samples were then placed in a $95^{\circ} \mathrm{C}$ water bath for $30 \mathrm{~min}$. After removal from the water bath and cooling to $60^{\circ} \mathrm{C}, 100 \mu \mathrm{l}$ of glucoamylase enzyme (Diazyme L-200, Valley Research Inc., South Bend, IN) was added. The test tube was recapped, gently mixed, and incubated overnight at $60^{\circ} \mathrm{C}$ with mixing every $4 \mathrm{~h}$. Each sample was mixed thoroughly and an aliquot transferred into a $12 \times 75 \mathrm{~mm}$ centrifuge tube that was centrifuged at $3000 \times \mathrm{g}$ for $10 \mathrm{~min}$. The samples were then decanted into autoanalyzer cups and stored at $4^{\circ} \mathrm{C}$ until analysis for glucose by an automated glucose oxidase/peroxidase enzyme procedure (Technicon Instruments Corp., Tarrytown, NY). Starch content was calculated by multiplying the glucose concentration by 0.9 .

Starch disappearance (modified from Tilley and Terry, 1963) was measured by incubating $0.5 \mathrm{~g}$ sample of grain, cleaned and ground as previously described. Triplicate samples were weighed into $100-\mathrm{ml}$ polypropylene centrifuge tubes. Ruminal fluid inoculum was prepared by obtaining whole ruminal contents from a ruminally fistulated steer maintained on a $92.5 \%$ concentrate (dry-rolled corn and supplement) diet containing $5 \%$ corn silage ( $50 \%$ grain content, dry matter (DM) basis) and 5\% alfalfa hay (DM basis). Ruminal contents were squeezed through four layers of cheese cloth into a pre-warmed thermos and then strained through an additional four layers of cheese cloth into separatory funnels. The separatory funnels were gassed with $\mathrm{CO}_{2}$ and placed in a $39^{\circ} \mathrm{C}$ water bath for at least 20 min. After separation, settled and floating materials were discarded. Artificial saliva, with $1 \mathrm{~g}$ urea per liter added, was gassed with $\mathrm{CO}_{2}$ and warmed in a $39^{\circ} \mathrm{C}$ water bath. Ruminal fluid was combined with artificial saliva in $1: 1,1: 2,1: 3$, and $1: 4$ ratios to form ruminal fluid inocula. For each ruminal fluid:artificial saliva ratio, $30 \mathrm{ml}$ of inoculum was added to the triplicate grain samples. Tubes were gassed with $\mathrm{CO}_{2}$, stoppered, gently mixed, and placed in a $39^{\circ} \mathrm{C}$ water bath. Tubes were swirled every $2 \mathrm{~h}$ during incubation. At $4,8,12,16$, and $20 \mathrm{~h}, \mathrm{pH}$ was measured and fermentation was then stopped by the addition of $15 \mathrm{ml}$ of cold $1.2 \mathrm{M}$ acetate buffer in saturated benzoic acid.

Starch remaining was determined by adding $50 \mu$ of $\alpha$-amylase to each tube and incubating in a $95^{\circ} \mathrm{C}$ water bath for $30 \mathrm{~min}$. After removing the tubes from the water bath and allowing to cool to $60^{\circ} \mathrm{C}$, any $\mathrm{DM}$ apparent on the sides of the tubes was scraped back into the inoculum-buffer solution with a rubber policeman. Next, $0.25 \mathrm{ml}$ of glucoamylase was added, the tubes were stoppered, and incubated at $60^{\circ} \mathrm{C}$ overnight with swirling once after $2 \mathrm{~h}$. Tubes were rinsed three times with $0.2 \%$ benzoic acid as they were transferred to 100 $\mathrm{ml}$ volumetric flasks. Flasks were then brought to volume with the diluted henzoic acid, mixed thoroughly, and an aliquot was transferred to $12 \times 75 \mathrm{~mm}$ centrifuge tubes. Samples were centrifuged at $3000 \times \mathrm{g}$ for $10 \mathrm{~min}$. Samples were then decanted into autoanalyzer cups and stored at $4^{\circ} \mathrm{C}$ until glucose analysis, as in the original samples.

The IVRSD was calculated by dividing the amount of starch remaining after digestion by the original amount of starch, multiplying by 100 , and regressing the natural log of the five fermentation values and the 0 -h starch remaining value (100\%) against incubation time. The slope of the regression line represents the fractional rate of starch disappearing 
per hour. All starch-remaining values were also converted to starch disappearance by subtraction from 100. Disappearance values, for each inoculum dilution, were plotted against incubation time to determine a single incubation time that would be appropriate for estimating rate of starch digestion of sorghum grain.

In vitro measurements were analyzed as a completely randomized design according to the GLM procedures of Statistical Analysis Systems Institute Inc. (1989). Model effects included grain, inoculum, and residual error. Sums of squares for buffer were partitioned into linear, quadratic, and cubic contrasts (Steel and Torrie, 1980).

\subsection{Experiment 2 -Grinder type}

Six grain sorghum lines (the five sorghums from Experiment 1 plus KS57) and the control corn hybrid (from Experiment 1) were used to examine effects of grinder type and grind size on IVRSD. The grinder experiment used an Udy mill (cyclone type; Udy Corporation, Boulder, $\mathrm{CO}$ ) and a Wiley mill to grind grain samples through a 1-mm screen. Starch in the original samples was determined as previously described, and starch disappearance was modified as follows. Ruminal fluid was collected from a steer maintained on a $92.5 \%$ concentrate diet with the grain of the concentrate consisting of $50 \%$ dry-rolled corn and 50\% dry-rolled sorghum; 1:1 and 1:2 ruminal fluid:artificial saliva ratios were used; $\mathrm{pH}$ was not measured, and fermentation was stopped at $8 \mathrm{~h}$. In vitro starch disappearance was calculated by dividing the amount of starch remaining after digestion by the original amount of starch, multiplying by 100 , and then subtracting that value from 100 .

In vitro starch disappearance was analyzed as a completely randomized design according to the GLM procedures of Statistical Analysis Systems Institute Inc. (1989). Model effects included grinder type, grain, ruminal fluid ratio, grinder $\times$ grain, grinder $\times$ ruminal fluid ratio, and grain $\times$ ruminal fluid ratio as independent variables. The grain $\times$ ruminal fluid ratio was not significant $(P=0.33)$ and was removed from the analysis. The least significant difference was used for all mean comparisons when a significant $(P<0.10)$ F-test was noted.

\subsection{Experiment 3-Grinder screen size}

A grinder screen size experiment was conducted as described in Experiment 2, with the following exceptions. Grain samples were ground through a Wiley mill equipped with either a 1-mm or 2-mm screen; only a 1:1 ruminal fluid:artificial saliva ratio was used. Statistical analysis was the same as described in Experiment 2 except grinder screen size and grain were the independent variables.

\subsection{Experiment 4-Ruminal fluid donor diet}

Three ruminally fistulated cattle $(473 \mathrm{~kg})$ were used in a replicated $3 \times 3$ Latin square design to determine the effect of type of grain (dry-rolled corn, dry-rolled sorghum, or $50 \%$ corn and $50 \%$ sorghum) in the diet of the ruminal fluid donors on the ranking of grain samples digested in vitro. Cattle were adjusted to $92.5 \%$ concentrate finishing diets using three adaptation diets containing 65 ( 6 days), 75 ( 3 days), and $85 \%$ ( 5 days) concentrate 
Table 1

Composition of diets fed to ruminal fluid donor cattle

\begin{tabular}{lccc}
\hline & \multicolumn{2}{l}{ Diet (\% DM basis) } & \\
\cline { 2 - 4 } & Corn & Sorghum & Corn/sorghum \\
\hline Dry rolled corn & 82.89 & - & 41.44 \\
Dry rolled grain sorghum & - & 82.89 & 41.45 \\
Ground alfalfa hay & 5.00 & 5.00 & 5.00 \\
Corn silage & 5.00 & 5.00 & 5.00 \\
Molasses-urea supplement & 5.00 & 5.00 & 5.00 \\
Limestone & 1.46 & 1.46 & 1.46 \\
Potassium chloride & 0.35 & 0.35 & 0.35 \\
Sodium chloride & 0.30 & 0.30 & 0.30 \\
\hline
\end{tabular}

${ }^{a}$ Supplement was based on a molasses-urea liquor and contained (DM basis) $50.6 \% \mathrm{CP}, 2.61 \% \mathrm{~K}, 0.95 \% \mathrm{Ca}$, $0.55 \% \mathrm{P}, 0.41 \% \mathrm{~S}, 0.35 \% \mathrm{Mg}, 78830 \mathrm{IU}$ of vitamin $\mathrm{A} \mathrm{kg}^{-1}, 15770 \mathrm{IU}$ of vitamin $\mathrm{D} \mathrm{kg}^{-1}$, and $20 \mathrm{IU}$ of vitamin $\mathrm{E} \mathrm{kg}^{-1}$.

(DM basis). The grain in the adaptation diets consisted of $50 \%$ dry-rolled corn and $50 \%$ dry-rolled sorghum. Final dicts contained (DM basis) $82.9 \%$ grain, 5\% ground alfalfa hay, $5 \%$ corn silage, $5 \%$ molasses-urea liquor based supplement $(50.6 \% \mathrm{CP})$, and $2.1 \%$ minerals (Table 1). Diets were $81 \% \mathrm{DM}, 11.9 \% \mathrm{CP}, 7 \% \mathrm{Ca}$, and.3\% P (DM basis) and were fed on an equal energy basis per unit of body weight every $3 \mathrm{~h}$. Experimental periods included 10 days adaptation and a 1 day sampling before feeding on the morning of the 11th day. Ruminal fluid was collected as described in the previous trials. The six grain sorghum lines described in Experiment 2, two high lysine corn hybrids (Crows SL48; Crows Hybrid Corn Co., Milford, IL) grown over two different years, two dry corn hybrids (Pioneer 3183; Fontanelle 6235; Fontanelle Hybrid, Nickerson, NE), and one high moisture corn (mixed hybrid) were used for digestion in vitro. All grain samples were ground to pass through a 1-mm screen in a Wiley grinder and a 1:1 ruminal fluid:artificial saliva ratio was used to digest grains for $4,8,12,16$, and $24 \mathrm{~h}$. All three diets were compared each period within an in vitro run. The in vitro rate of starch disappearance was measured and calculated as previously described in Experiment 1, except the 24-h measurement replaced a 20-h measurement.

The IVRSD was analyzed as a replicated Latin square design using the GLM procedures of Statistical Analysis Systems Institute Inc. (1989) with replication over time, period, animal, diet, grain digested in vitro, and diet $\times$ grain digested in vitro as independent variables. Mean comparisons were made using the least significant difference method protected by a significant F-test.

\section{Results and discussion}

\subsection{Experiment 1 -Ruminal fluid:inoculum ratios}

In vitro rate of starch disappearance and coefficient of determination were similar for the $1: 2,1: 3$, and 1:4 inoculum dilutions, and were higher (quadratic, $P<0.01$ ) than the $1: 1$ 
Table 2

Effect of ruminal fluid:artificial saliva ratios on in vitro rates of starch disappearance, coefficients of determination, and $\mathrm{pH}$ in Experiment 1

\begin{tabular}{lllr}
\hline Inoculum & \multicolumn{2}{l}{ In vitro rate of starch disappearance ${ }^{\mathrm{a}}$} & $\mathrm{pH}^{\mathrm{c}}$ \\
\cline { 2 - 4 } & Rate $\left(\% \mathrm{~h}^{-1}\right)^{\mathbf{b}}$ & $R^{2 \mathrm{~b}}$ & 5.95 \\
\hline $1: 1$ & 6.68 & 0.87 & 6.26 \\
$1: 2$ & 8.89 & 0.96 & 6.36 \\
$1: 3$ & 9.81 & 0.97 & 6.46 \\
$1: 4$ & 8.89 & 0.93 & 0.02 \\
$\mathrm{SE}$ & 0.45 & 0.01 & \\
\hline
\end{tabular}

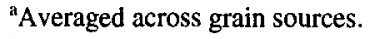

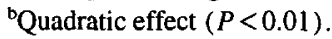

${ }^{c}$ Averaged across grain sources and hours; linear effect $(P<0.01)$.

dilution (Table 2). As the level of artificial saliva increased in the inoculum, in vitro $\mathrm{pH}$ increased (linear, $P<0.01$ ).

In an in vitro study of digesting potato and Zulkovsky starch, Cone (1991) found that in vitro $\mathrm{pH}$ dropped from 6.5 to 5.2 during the first $6 \mathrm{~h}$ of incubation and then remained constant. The decrease in $\mathrm{pH}$ did not affect the rate of digestion up to $6 \mathrm{~h}$ but reduced rates of disappearance and extent of digestion at $24 \mathrm{~h}$. In Cone's study, using a stronger buffer proved unsuitable because it decreased microbial activity. We found that increasing the ratio of McDougal's buffer to ruminal fluid increased $\mathrm{pH}(P<0.01$; Table 2$)$. However, even with the 1:1 inoculum ratio, $\mathrm{pH}$ did not drop below 5.55 for the corn and wheat, or 5.85 for sorghum over the $20-\mathrm{h}$ incubation period. As the ratio of artificial saliva increased, IVRSD and the coefficients of determination increased with highest values occurring at a dilution of 1:3. When a 1:4 inoculum ratio was used, IVRSD and the coefficients of determination decreased slightly (quadratic, $P<0.01$ ), possibly indicating a level of reduced microbial activity. Although $1: 1$ inoculum ratios are used throughout the other experiments reported herein (a 1:1 inoculum ratio was part of our previous standard operating procedures), a ruminal fluid:artificial saliva ratio of 1:2 or 1:3 appears to be more appropriate for estimating IVRSD on grain samples with rapid or wide range of starch digestion rates.

Using similar in vitro starch techniques, Wester et al. (1992) stated that a 9-h IVRSD measurement could be used for evaluation of sorghum grain because 9-h values appeared to be in the middle of the linear portion of the digestion curve. After plotting the starch disappearance values for these widely divergent grain samples against incubation time, we determined that the 8-h measurements for both the 1:1 (Fig. 1) and 1:2 (Fig. 2) dilutions were in the middle of the digestion curve and could be used for evaluating digestibility of grains. Although 8-h and 9-h digestion periods have both been shown to be in the middle of the sorghum digestion curve, the 8-h digestion period is much better practically because it allows for a shorter work day for personnel.

In summary, a ruminal fluid:artificial saliva ratio of $1: 2$ or 1:3 will increase the buffering capacity of the in vitro system without reducing the microbial digestion rates and are appropriate over a large range of starch digestibility rates. Evaluating starch digestibility of 


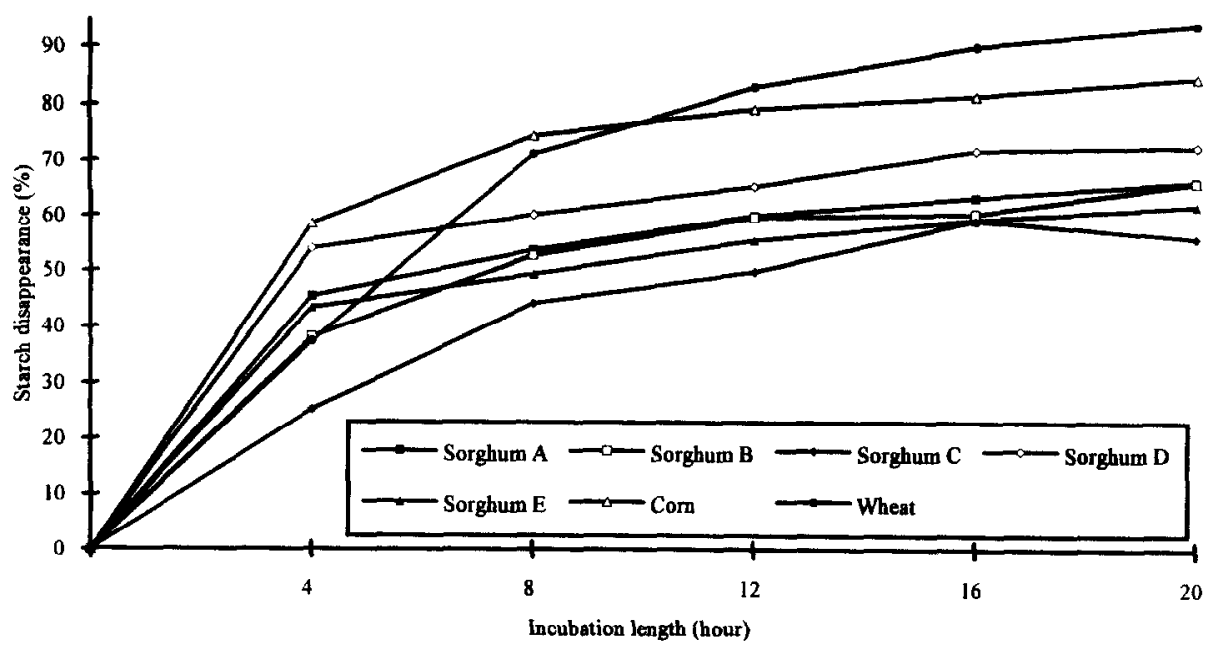

Fig. 1. Starch disappearance values plotted against incubation length with a 1:1 ruminal fluid:artificial saliva ratio.

sorghum grain samples for an 8-h incubation period allows reliable and convenient evaluation of large numbers of samples.

\subsection{Experiment $2-$ Grinder type}

In the grinder type experiment, the interaction between inoculum ratio and grinder type was significant $(P<0.01)$ because of a different ranking of the grains ground through the Udy mill when the artificial saliva ratio was changed. An interaction between grain and grinder type occurred $(P<0.01)$ because the samples ground through the Udy mill and digested in either inoculum ratio were ranked differently from the samples ground through

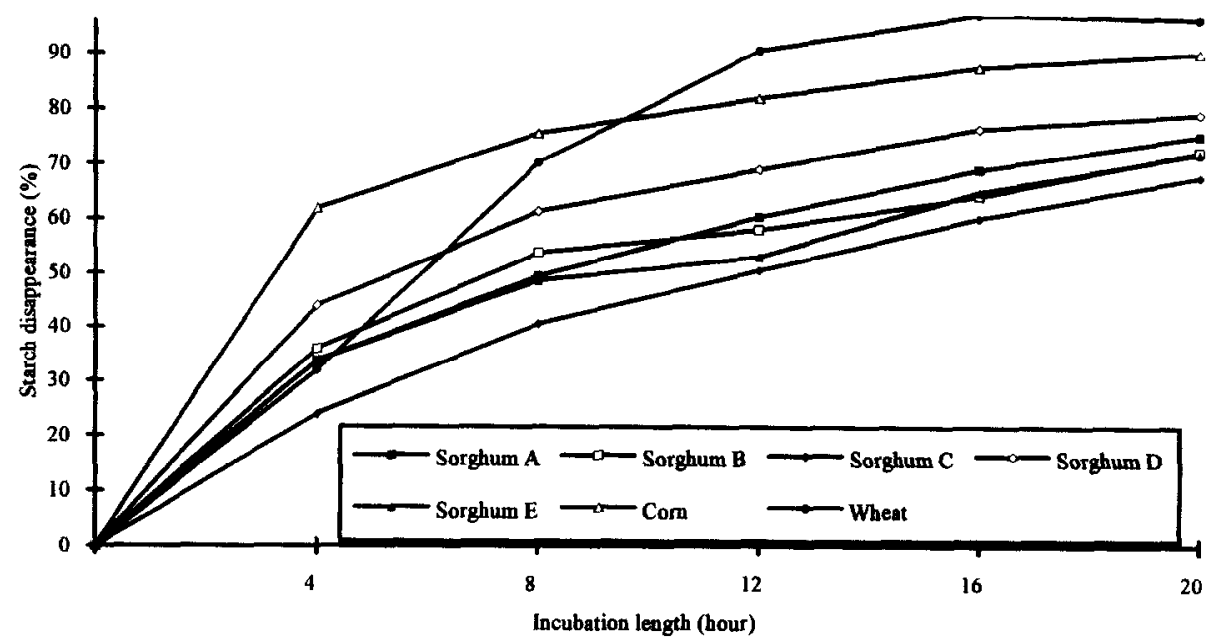

Fig. 2. Starch disappearance values plotted against incubation length with a $1: 2$ ruminal fluid:artifical saliva ratio. 
Table 3

Effects of Udy and Wiley 1-mm grind on 8-h in vitro starch disappearance (percentage, DM basis) in Experiment $2^{\mathrm{a}}$

\begin{tabular}{|c|c|c|c|c|c|c|c|c|c|}
\hline \multirow[t]{3}{*}{ Grain } & & \multicolumn{4}{|l|}{ Udy mill } & \multicolumn{4}{|l|}{ Wiley mill } \\
\hline & & \multicolumn{2}{|l|}{$1: 1^{\mathrm{b}}$} & \multicolumn{2}{|l|}{$1: 2$} & \multicolumn{2}{|l|}{$1: 1$} & \multicolumn{2}{|l|}{$1: 2$} \\
\hline & & $\begin{array}{l}\text { Starch } \\
\text { disappearance }\end{array}$ & Rank & $\begin{array}{l}\text { Starch } \\
\text { disappearance }\end{array}$ & Rank & $\begin{array}{l}\text { Starch } \\
\text { disappearance }\end{array}$ & Rank & $\begin{array}{l}\text { Starch } \\
\text { disappearance }\end{array}$ & Rank \\
\hline \multirow[t]{6}{*}{ Sorghum } & A & 84.4 & 6 & 92.9 . & 7 & 53.9 & 4 & 56.2 & 5 \\
\hline & B & 79.6 & 2 & 89.4 & 4 & 50.6 & 3 & 50.9 & 3 \\
\hline & C & 84.6 & 7 & 89.9 & 5 & 39.8 & 1 & 38.2 & 1 \\
\hline & $\mathrm{D}$ & 78.0 & 1 & 86.4 & 1 & 63.8 & 6 & 71.0 & 6 \\
\hline & $\mathrm{E}$ & 81.3 & 4 & 90.6 & 6 & 47.1 & 2 & 47.2 & 2 \\
\hline & $\mathrm{F}$ & 79.7 & 3 & 86.8 & 2 & 54.0 & 5 & 55.4 & 4 \\
\hline Corn & & 82.4 & 5 & 88.1 & 3 & 84.4 & 7 & 86.9 & 7 \\
\hline Average $^{c}$ & & $81.4^{\mathrm{d}}$ & & $89.2^{\mathbf{e}}$ & & $56.3^{\mathrm{f}}$ & & $58.0^{\mathrm{g}}$ & \\
\hline
\end{tabular}

${ }^{a}$ Inoculant ratio $\times$ grinder type for starch disappearance $(P<0.01)$; grain $\times$ grinder type for starch disappearance $(P<0.01)$.

bInoculant ratio.

'Standard error for starch disappearance $=0.6$.

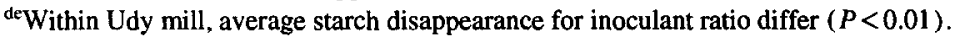

${ }^{\mathrm{g}}$ Within Wiley mill, average starch disappearance for inoculant ratio differ $(P<0.10)$.

the Wiley mill. The percentage of starch disappearance for the samples ground through the Udy mill was higher than samples ground in the Wiley mill ( 85.3 vs. 57.2 , respectively) when averaged across buffers (Table 3 ). Visually, the particle size of the samples ground through the Udy mill appeared to be smaller resulting in increased surface area. The increased surface area would have increased the amount of starch digested in $8 \mathrm{~h}$ of in vitro fermentation.

The high starch disappearance ( $85.3 \%, \mathrm{DM}$ basis) of the Udy ground samples at $8 \mathrm{~h}$ is approaching total extent $(90-95 \%)$ of starch digestion and reduced our ability to rank consistently Udy mill ground samples for IVRSD. Samples ground with the Wiley mill were ranked consistently, and differences in IVRSD values among the sorghum lines were relatively large, which would allow a greater potential for detecting genetic differences in the grain.

\subsection{Experiment 3 -Grinder screen size}

Samples ground through a Wiley mill to pass a 1 -mm screen had lower $(P<0.10)$ percent starch disappearance and rankings differed for only two grains compared with samples ground through the same mill with a 2-mm screen (Table 4). Although the starch disappearance values were different between the 1-and 2-mm grinds, the average difference was only 3.1 percentage units. Cone et al. (1989) also found a fairly constant ranking between various feedstuffs. But, in that study, the rates of disappearance increased with sieved particle size decreasing from $1 \mathrm{~mm}$ to $0.1 \mathrm{~mm}$. 
Table 4

Effects of Wiley 1-mm and 2-mm grind on $8 \mathrm{~h}$ in vitro starch disappearance in Experiment 3

\begin{tabular}{|c|c|c|c|c|c|}
\hline \multirow[t]{2}{*}{ Grain } & & \multicolumn{2}{|l|}{$1-\mathrm{mm}$} & \multicolumn{2}{|l|}{$2-\mathrm{mm}$} \\
\hline & & Starch disappearance & $\mathrm{CV}$ & Starch disappearance & $\mathrm{CV}$ \\
\hline \multirow[t]{6}{*}{ Sorghum } & A & $36.9(4)^{\mathrm{a}}$ & 0.3 & $40.0(4)$ & 2.8 \\
\hline & B & $34.4(3)$ & 1.4 & $36.5(3)$ & 1.3 \\
\hline & $\mathrm{C}$ & $23.8(1)$ & 1.8 & $35.3(2)$ & 2.2 \\
\hline & $\mathrm{D}$ & $45.2(6)$ & 1.5 & $43.3(6)$ & 2.1 \\
\hline & $\mathrm{E}$ & $32.8(2)$ & 0.7 & $33.7(1)$ & 2.0 \\
\hline & $F$ & $38.2(5)$ & 0.0 & $42.0(5)$ & 1.2 \\
\hline Corn & & $59.0(7)$ & 1.5 & $61.3(7)$ & 12.0 \\
\hline Average $^{\text {tc }}$ & & 38.6 & 1.1 & 41.7 & 3.4 \\
\hline
\end{tabular}

"Numbers within parentheses are relative rankings.

${ }^{\mathrm{b}} \mathrm{Standard}$ error of starch disappearance $=1.1$; average starch disappearances differ $(P<0.09)$.

"Standard error of coefficient of variation $=1.0$ : coefficient of variation tends to differ $(P<0.14)$.

\subsection{Experiment 4-Ruminal fluid donor diet}

The IVRSD of grain samples incubated in rumen inoculum from donor animals fed the sorghum diet was the fastest $(P<0.01$; Table 5$)$. The IVRSD of the grain samples incubated in rumen inoculum from donor animals fed the corn/sorghum and the corn diets did not differ significantly. Interactions between donor diet and grains digested were not significant $(P=0.99)$ indicating similar rankings of the grains digested in vitro. These results are similar to findings of Cone et al. (1989) and Trei et al. (1970) that compared in vitro

Table 5

Effects of donor diet on in vitro rate of starch disappearance in Experiment 4

\begin{tabular}{|c|c|c|c|c|c|c|c|}
\hline & & \multicolumn{2}{|l|}{ Corn } & \multicolumn{2}{|l|}{ Sorghum } & \multicolumn{2}{|c|}{ Corn/sorghum } \\
\hline & & Rate, $\% / \mathrm{h}$ & Rank & Rate, $\% / \mathrm{h}$ & Rank & Rate, $\% / \mathrm{h}$ & Rank \\
\hline \multirow[t]{6}{*}{ Sorghum } & $\mathrm{A}$ & $7.9^{\mathrm{a}}$ & 5 & $10.0^{\mathrm{a}}$ & 4 & $8.3^{\mathrm{ab}}$ & 5 \\
\hline & B & $7.2^{\mathrm{a}}$ & 4 & $10.2^{\mathrm{a}}$ & 5 & $8.0^{\mathrm{a}}$ & 3 \\
\hline & $\mathrm{C}$ & $6.4^{\mathrm{a}}$ & 3 & $9.7^{a}$ & 3 & $8.1^{\mathrm{ab}}$ & 4 \\
\hline & $\mathrm{D}$ & $8.2^{\mathrm{a}}$ & 6 & $10.2^{\mathrm{a}}$ & 6 & $8.4^{b}$ & 6 \\
\hline & $\mathrm{E}$ & $6.0^{\mathrm{n}}$ & 1 & $8.4^{a}$ & 1 & $6.9^{\mathrm{a}}$ & 1 \\
\hline & $\mathrm{F}$ & $6.3^{\mathrm{a}}$ & 2 & $9.0^{\mathrm{a}}$ & 2 & $7.5^{\mathrm{a}}$ & 2 \\
\hline \multirow[t]{2}{*}{ High-lysine corn } & A & $13.7^{\mathrm{bc}}$ & 10 & $15.6^{\mathrm{b}}$ & 10 & $13.3^{\mathrm{c}}$ & 10 \\
\hline & B & $12.5^{\mathrm{bx}}$ & 9 & $14.7^{\mathrm{b}}$ & 9 & $13.0^{\circ}$ & 9 \\
\hline Dry corn & & $15.1^{\mathrm{c}}$ & 11 & $16.3^{b}$ & 11 & $13.3^{\mathrm{c}}$ & 11 \\
\hline High-moisture corn & & $12.4^{\mathrm{hc}}$ & 8 & $13.5^{\mathrm{b}}$ & 8 & $11.7^{\mathrm{c}}$ & 8 \\
\hline Control corn & & $11.3^{\mathrm{b}}$ & 7 & $13.5^{\circ}$ & 7 & $10.7^{\mathrm{bc}}$ & 7 \\
\hline Average $^{d}$ & & $9.7^{\mathrm{e}}$ & & $11.9^{f}$ & & $9.9^{\mathrm{e}}$ & \\
\hline
\end{tabular}

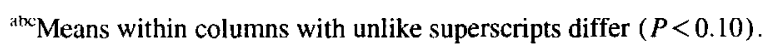

${ }^{\mathrm{d} S t a n d a r d}$ error of the mean $=0.35$.

${ }^{\text {et }}$ A verages with unlike superscripts differ $(P<0.01)$. 
starch disappearance and gas production using ruminal fluid from donors on forage and concentrate diets. It appears that ranking of grains for IVRSD is independent of the diet of the ruminal fluid donor animal. However, if IVRSD values are to be compared among in vitro runs, the diet of the donor animal must remain constant.

\section{Conclusions}

Variability in ruminal starch digestion among grain sorghum lines exists. The IVRSD procedure is an appropriate measure for determining the ruminal starch availabilities of cereal grains. Usc of a singlc measurement at $8 \mathrm{~h}$, using samples ground through a Wiley mill, would allow for IVRSD to be used for applications requiring evaluation of a large number of samples, such as in genetic improvement of grain quality. Absolute rates of digestion will vary according to the source of ruminal fluid, the ratio at which ruminal fluid is combined with artificial saliva, and the grinder type used, yet, IVRSDs can be compared within in vitro run and ranking of the samples can be compared within or between runs.

\section{Acknowledgements}

This research was conducted in part through funding provided by Pioneer Hi-Bred International, Inc., Johnston, IA.

\section{References}

Cone, J.W., 1991. Degradation of starch in feed concentrates by enzymes, rumen fluid and rumen enzymes. J. Sci. Food Agric., 54: 23-34.

Cone, J.W., Wilhelmina, C., Malestein, A. and Klooster, A., 1989. Degradation of starch by incubation with rumen fluid. A comparison of different starch sources. J. Sci. Food Agric., 49: 173-183.

Hibberd, C.A., Mitchell, E.D., Wagner, D.G. and Hintz, R.L.x 1979. Seed characteristics of different varieties of grain sorghum. Oklahoma Anim. Sci. Res. Rep. MP-104, 16.

Hibberd, C.A., Wagner, D.G., Hintz, R.L. and Griffen, D.D., 1983. Effect of sorghum grain variety and processing method on the site and extent of digestion in steers. Oklahoma Anim. Sci. Res. Rep. Sta. MP-104, 28.

MacRae, J.C. and Armstrong, D.G. 1968. Enzyme method for determination of alpha-linked glucose polymers in biological materials. J. Sci. Food Agric., 19: 578-581.

McCollough, R.L., Riley, J.G., Drake, C.L. and Roth, G.M., 1972. Fcedlot performance on ninc hybrid sorghum grains fed to steers winter, 1971-1972. Kansas Agric. Exp. Sta. Bull. 557, 37.

McDougall, E.I., 1948. Studies in ruminant saliva. I. The composition and output of sheep saliva. Biochem. J., 43: 99-109.

$\emptyset$ rskov, E.R., 1986. Starch digestion and utilization in ruminants. J. Anim. Sci., 63: 1624.

Rooney, L.W. and Pflugfelder, R.L., 1986. Factors affecting starch digestibility with special emphasis on sorghum and corn. J. Anim. Sci., 63: 1607.

Sherrod, L.B., Albin, R.C. and Furr, R.D., 1969. Net energy of regular and waxy sorghum grains for finishing steers. J. Anim. Sci., 29: 997.

Statistical Analysis Systems Institute Inc., 1989. SAS User's Guide. SAS Institute, Cary, NC.

Steel, R.G. and Torrie, J.H., 1980. Principles and Procedures of Statistics. McGraw-Hill, New York, NY.

Streeter, M.N., Wagner, D.G., Hibberd, C.A. and Buchanna, D.S., 1986. In vitro dry matter disappearance and in vitro gas production of sorghum grain varieties. Oklahoma Anim. Sci. Res. Rep. MP 125, 175 pp. 
Streeter, M.N., Wagner, D.G., Hibberd, C.A., Mitchell Jr., E.D. Jr. and Oltjen, J.W. 1990. Effect of variety of sorghum grain on digestion and availability of dry matter and starch in vitro. Anim. Feed Sci. Technol., 29: 279.

Streeter, M.N., Wagner, D.G., Owens, F.N., and Hibberd, C.A., 1991. The effect of pure and partial yellow endosperm sorghum grain hybrids on site and extent of digestion in beef steers. J. Anim. Sci., 69: 2571 .

Tilley, J.M.A. and Terry, R.A., 1963. A two-stage technique for the in vitro digestion of forage crops. J. Br. Grassl. Soc., 18: 104-111.

Trei, J., Hale, H.W., Theurer, B., 1970. Effects of grain processing on in vitro gas production. J. Anim. Sci., 30: 825-831.

Wester, T.J., Gramlich, S.M., Britton, R.A., and Stock, R.A., 1992. Effect of grain sorghum hybrid on in vitro rate of starch disappearance and finishing performance of ruminants. J. Anim. Sci., 70: 2866-2876. 